\title{
Hubungan Motivasi Belajar terhadap Hasil Belajar Passing dalam Sepak Bola
}

\section{Relationship between Learning Motivation and Passing Learning Outcomes in Soccer}

\author{
Budiman' $^{1}$, Taufik Rouf ${ }^{2}$, Ali Budiman ${ }^{3}$ \\ 1,2,3 Program studi PJKR, STKIP Pasundan, Cimahi, Jawa Barat, 40513, Indonesia
}

\begin{abstract}
Abstrak
Tujuan penelitian ini untuk mengetahui hubungan antara motivasi belajar dengan hasil belajar passing dalam sepak bola. Metode yang digunakan dalam penelitian adalah metode korelasional. Populasi penelitian ini adalah seluruh siswa kelas VIII SMP AlMussyarofah Cianjur berjumlah 83 siswa. Sampel yang terpilih adalah kelas VIII B sebanyak 27 siswa yang diambil secara cluster random sampling. Instrumen yang digunakan adalah skala motivasi belajar dan tes keterampilan passing dalam sepak bola. Analisis data pada penelitian ini menggunakan SPSS 23 dengan teknik bivariate. Hasil penelitian menunjukkan nilai $\mathrm{r}$ 0,719 dan Sig. (2-tailed) $0,000<0,005$. Berdasarkan hasil penelitian dapat disimpulkan bahwa terdapat hubungan yang signifikan antara motivasi belajar dengan hasil belajar passing dalam sepak bola.

Kata kunci: Pendidikan jasmani, motivasi belajar, hasil belajar passing dalam sepak bola.
\end{abstract}

\begin{abstract}
The purpose of this study was to determine the relationship between learning motivation and passing learning outcomes in soccer. The method used in this research is the corelational method. The population of this study were all eighth grade students of SMP AlMussyarofah Cianjur totaling 83 students. The sample chosen was class VIII B as many as 27 students who were taken by cluster random sampling. The instrument used was a scale of learning motivation and a test of passing skills in soccer. Data analysis in this study used SPSS 23 with the bivariate technique. The results showed that the $r$ value was 0.719 and Sig. (2-tailed) $0.000<0.005$. Based on the results of the study, it can be concluded that there is a significant relationship between learning motivation and the results of passing learning outcomes in soccer.
\end{abstract}

Keywords: Physical education, learning motivation, passing learning outcomes in soccer. 


\section{PENDAHULUAN}

Pendidikan jasmani secara tradisional dianggap sebagai bagian penting dari kurikulum untuk mempromosikan berbagai manfaat termasuk kesehatan, pengembangan kognitif, keterampilan motorik dan perilaku sosial (Bailey et al., 2009). Pendidikan jasmani dapat diartikan sebagai suatu proses pendidikan dengan menggunakan aktivitas fisik dan olahraga sebagai media atau alat pembelajaran untuk mengembangkan pengetahuan, sikap dan keterampilan siswa. Kemudian, Bucher (dalam Suherman, 2009, p. 7) mengklasifikasikan tujuan pendidikan jasmani dalam empat kategori yaitu: Perkembangan fisik, perkembangan gerak, perkembangan mental dan perkembangan sosial. Perkembangan fisik berhubungan dengan kemampuan melakukan ativitas yang melibatkan kekuatan fisik dari berbagai organ tubuh. Perkembangan gerak berhubungan dengan kemampuan melakukan gerak secara efektif, efisien, halus, indah, sempurna. Perkembangan mental berhubungan dengan kemampuan berpikir dan menginterpretasikan keseluruhan pengetahuan tentang pendidikan jasmani kedalam lingkungannya. Perkembangan sosial berhubungan dengan kemampuan siswa dalam menyesuaikan diri pada suatu kelompok atau masyarakat.

Permainan bola besar melalui sepak bola merupakan salah satu materi yang terdapat dalam pembelajaran pendidikan jasmani (Amir Supriadi, 2015; Hidayatullah, 2017; Wijayanto, 2012). Permainan tersebut menekankan pada pemanfaatan bentukbentuk permainan dan aktivitas gerak sebagai alat untuk belajar. Melalui sepak bola siswa diharapkan mempunyai kepekaan perasaan dan afektif sehingga siswa dapat menunjukkan rasa empati, toleransi, saling menghargai dan menghormati. Melalui permainan sepak bola diharapkan dapat melatih perilaku sosial siswa, dengan cara menunjukkan perilaku sosial yang baik, seperti mau bekerja sama, menghargai dan menghormati kawan dan lawan bermain. Kemudian, melalui sepak bola siswa dapat meningkatkan keterampilan gerak.

Namun, fenomena yang sering terjadi di lapangan ketika berlangsung proses pembelajaran sepak bola siswa kurang menunjukkan kegigihan dan usaha yang maksimal, sehingga hasil pembelajaran passing dalam sepak bola masih bisa dikatakan belum optimal (Muta'al, 2019; Naldi \& Irawan, 2020; Yudi, 2019). Jika hal tersebut terjadi, mengisyaratkan adanya kesulitan belajar pada diri siswa. Kesulitan belajar tersebut, patut diduga salah satunya berkaitan erat dengan motivasi belajar yang dimilikinya, karena Menurut Santrock (2010, p. 510) motivasi adalah proses yang memberi semangat, arah dan kegigihan perilaku. Perilaku yang termotivasi adalah perilaku yang penuh energi, terarah dan bertahan lama. Moore (2009, p. 334) motivasi adalah “... what gets you going, 
keeps you going, and determines where you're trying to go". Lebih lanjut, Ormrod (2003, p. 368) mengungkapkan bahwa "motivation is something that energizes, direct, and sustains behavior, it gets students moving, points them in particular direction, and keeps them going." Pengertian tersebut senada dengan yang disampaikan Hamdu \& Agustina (2019) dengan adanya motivasi, siswa akan belajar lebih keras, ulet, tekun dan memiliki konsentrasi penuh dalam proses belajar pembelajaran. Schunk (2010, p. 5) Motivasi membawa suatu hubungan timbal balik antara proses belajar dan kemampuan belajar. Artinya, motivasi mempengaruhi proses belajar dan proses pembelajaran juga mempengaruhi motivasi peserta didik (Indaryati \& Jailani, 2015).

Dari uraian di atas, penulis tertarik untuk mengetahui lebih dalam kondisi tersebut melalui penelitian mengenai hubungan motivasi belajar terhadap hasil belajar passing dalam sepak bola.

\section{METODE}

Metode yang digunakan dalam penelitian ini adalah metode deskriptif dengan teknik korelasional. Populasi penelitian ini adalah seluruh siswa kelas VIII SMP Al-Mussyarofah Cianjur berjumlah 83 siswa. Sampel yang terpilih adalah kelas VIII B sebanyak 27 siswa yang diambil secara cluster random sampling. Penyusunan instrumen penelitian merupakan salah satu rangkaian kegiatan yang sangat penting dalam penelitian, karena dengan instrumen penelitian dapat mengumpulkan data yang esensial dipergunakan guna memecahkan masalah. Dalam penelitian ini instrumen penelitian yangdigunakan adalah Instrumen skala motivasi belajar dan tes keterampilan passing dalam sepak bola (Nurhasan, 2013, p. 157). Analisis data pada penelitian ini menggunakan SPSS 23 dengan teknik bivariate.

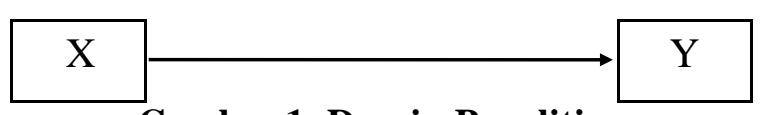

Gambar 1. Desain Penelitian

Keterangan:

$\mathrm{X}$ : Motivasi belajar.

Y : Hasil belajar passing dalam sepak bola.

\section{HASIL DAN PEMBAHASAN}

\section{Hasil}

Pengujian analisa korelasi untuk menguji hipotesis penelitian dilakukan setelah melakukan uji praanalisis berupa uji asumsi yang terdiri dari uji normalitas dan uji 
linearitas. Uji normalitas dilakukan untuk mengetahui sebaran data pada populasi berdistribusi secara normal atau tidak. Pengujian dilakukan dengan menggunakan One Sample Kolmogorov Smirnov Test pada SPSS 23 for Windows. Data memiliki distribusi normal jika memiliki nilai koefisien $\mathrm{p}>0,05$, sedangkan data memiliki distribusi tidak normal jika memiliki nilai koefisien $\mathrm{p}<0,05$. Berdasarkan pengujian normalitas pada variabel motivasi belajar didapatkan nilai koefisien $\mathrm{p}=0,948$ ( $\mathrm{p}>0,05)$. Hal ini menunjukkan bahwa variabel motivasi belajar memiliki distribusi data normal. Sedangkan untuk variabel hasil belajar passing dalam sepak bola, diketahui bahwa nilai koefisien $\mathrm{p}=0,088(\mathrm{p}>0,05)$. Hal ini menunjukkan bahw a variabel hasil belajar passing dalam sepak bola memiliki distribusi data normal. Hasil uji normalitas dapat diketahui melalui tabel berikut:

Tabel 1. Hasil Uji Normalitas

\begin{tabular}{cccc}
\hline & Kolmogorv-Smirnov & $\begin{array}{c}\text { Asymp. Sig. } \\
\text { (2- tailed) }\end{array}$ & Keterangan \\
\hline Motivasi Belajar & 0,522 & 0,948 & Data Normal \\
\hline Passing & 1,250 & 0,088 & Data Normal \\
\hline
\end{tabular}

Uji linearitas dilakukan untuk mengetahui apakah hubungan vaiabel tergantung dan variabel tidak tergantung memiliki hubungan linear. Hubungan antara kedua variabel dikatakan linear apabila $\mathrm{p}>0,05$, sedangakan hubungan kedua variabel dikatakan tidak linear apabila $\mathrm{p}<0,05$. Hasil uji linearitas menunjukkan bahwa $\mathrm{p}=0,125(\mathrm{p}>0,05)$. Hal ini menunjukkan bahwa terdapat hubungan linear antara motivasi belajar dan hasil belajar passing dalam sepak bola. Hasil uji linearitas dapat dilihat pada tabel berikut:

Tabel 2. Hasil Uji Linearitas

\begin{tabular}{cc}
\hline $\begin{array}{c}\text { Sig. De viaton From } \\
\text { Linearity }\end{array}$ & Keterangan \\
\hline 0,125 & Data Linear \\
\hline
\end{tabular}

Uji hipotesis merupakan langkah dalam teknik analisa statistik untuk membuktikkan hipotesis penelitian ini diterima atau tidak. Uji hipotesa dilakukan setelah melakukan uji normalitas dan uji linieritas. Hasil uji normalitas sebelumnya menunjukkan bahwa kedua variabel memiliki distribusi data normal. Pada uji linearitas untuk kedua variabel adalah linear. Langkah untuk melakukan uji koefisien korelasi pada data yang berdistribusi normal adalah dengan melakukan uji korelasi Bivariate. Hasil analisis koefisien korelasi antara motivasi belajar dan hasil passing dalam sepak bola adalah menunjukkan nilai $\mathrm{r}=0.719$ dan $\mathrm{p}=0.000(\mathrm{p}<0,01)$. Hubungan yang signifikan ini 
membuat hipotesis diterima. Hal ini menunjukkan bahwa terdapat hubungan yang signifikan antara motivasi belajar dengan hasil passing dalam sepak bola. Hasil uji hipotesis dapat dilihat melalui tabel di bawah ini:

Tabel 3. Uji Korelasi Bivarate Pearson.

\begin{tabular}{cccc}
\hline \multicolumn{2}{c}{ Correlations } & $\begin{array}{c}\text { Motivasi } \\
\text { belajar }\end{array}$ & $\begin{array}{c}\text { Hasil belajar } \\
\text { passing dalam } \\
\text { sepak bola }\end{array}$ \\
\hline $\begin{array}{c}\text { Motivasi } \\
\text { belajar }\end{array}$ & Pearson Correlation & 1 &, 719 \\
& Sig. (2-tailed) & &, 000 \\
$\begin{array}{c}\text { Hasil belajar } \\
\text { passing } \\
\text { dalam sepak } \\
\text { bola }\end{array}$ & Pearson Correlation &, 719 & 27 \\
\hline
\end{tabular}

\section{Pembahasan}

Hasil analisis data di atas menunjukkan bahwa motivasi belajar memiliki hubungan signifikan terhadap hasil belajar passing dalam sepak bola siswa SMP AlMussyarofah Cianjur. Hal tersebut sesuai dengan hasil penelitian (Firmansyah, 2011; Kusurkar, Ten Cate, Vos, Westers, \& Croiset, 2013; Muola, 2010) bahwa motivasi belajar memiliki hubungan yang signifikan dengan hasil belajar siswa. Sehingga sebagaimana yang diungkapkan oleh Keller (dalam Nashar, 2004, p. 77) peningkatan hasil belajar siswa dipengaruhi oleh banyak faktor salah satunya adalah motivasi untuk belajar. Hal ini berarti bahwa jika siswa memiliki motivasi dalam belajar, maka prestasi belajarnya pun akan baik (tinggi). Sebaliknya jika siswa memiliki kebiasaan yang buruk dalam belajar, maka prestasi belajarnyapun akan buruk (rendah) (Hamdu \& Agustina, 2019). Pendapat tersebut senada dengan yang disampaikan Alhadi \& Saputra (2017) siswa yang memiliki motivasi belajar tinggi akan menunjukkan minat, konsentrasi, kegigihan serta selalu berorientasi pada proses dan hasil belajar. Namun sebaliknya, siswa yang kurang motivasi belajar akan menunjukkan kejenuhan, mudah putus asa, dan berusaha menghindari kegiatan pembelajaran.

Salah satu faktor internal yang dapat mempengaruhi prestasi belajar adalah motivasi belajar. Motivasi belajar ini akan mendorong seseorang untuk melakukan sesuatu sehingga mencapai tujuan (Mustaqim, 2020). Jika siswa terdorong untuk melakukan belajar, maka akan terjadi suatu pembelajaran yang efektif yang pada akhirnya akan menghasilkan prestasi belajar yang tinggi. Hal ini sejalan dengan pendapat Emda (2018) yang menyatakan bahw a motivasi belajar merupakan sesuatu keadaan yang terdapat pada diri seseorang siswa dimana ada suatu dorongan untuk melakukan sesuatu 
guna mencapai tujuan belajar. Gunawan \& Benty (2007) motivasi belajar merupakan dorongan yang membuat siswa semangat dalam belajar. Sardiman (2018, p. 75) motivasi belajar adalah keseluruhan daya penggerak di dalam diri siswa yang menimbulkan kegiatan belajar, yang menjamin kelangsungan dari kegiatan belajar dan memberikan arah pada kegiatan belajar, sehingga tujuan yang dikehendaki oleh subjek belajar itu dapat tercapai.

Dengan demikian, dalam proses pembelajaran motivasi merupakan salah satu aspek dinamis yang sangat penting (Sanjaya, 2010, p. 249). Pembelajaran akan berlangsung efektif apabila siswa memiliki motivasi dalam belajar (Emda, 2018), baik itu motivasi intrinsik, motivasi yang diarahkan oleh minat dalam tugas itu sendiri (Brown, 2011, p. 76), ataupun motivasi ekstrinsik, motivasi yang lebih diarahkan oleh rangsangan eksternal, seperti seperti persetujuan orang tua, guru, teman satu kelas, ancaman, hukuman, hadiah, nilai yang baik dan sebagainya. Dengan motivasi belajar, maka peserta didik mempunyai intensitas dan kesinambungan dalam proses pembelajaran yang diikuti (Suminah, Gunawan, \& Murdiyah, 2019), sehinga menghasilkan prestasi belajar yang tinggi.

\section{KESIMPULAN}

Pada bagian akhir dari penelitian ini, peneliti akan memaparkan kesimpulan yang dapat diambil berdasarkan temuan hasil penelitian. Berdasarkan hasil penelitian dapat disimpulkan bahwa terdapat hubungan yang signifikan antara motivasi belajar dengan hasil belajar passing dalam sepak bola.

\section{DAFTAR PUSTAKA}

Alhadi, S., \& Nanda Eka Saputra, W. (2017). The Relationship between Learning Motivation and Learning Outcome of Junior High School Students in Yogyakarta. 66(Yicemap), 138-141. https://doi.org/10.2991/yic emap-17.2017.23

Amir Supriadi. (2015). Hubungan Koordinasi Mata-Kaki terhadap Keterampilan Menggiirng Bola pada Permainan Sepakbola. Jurnal Ilmu Keolahragaan, 151(1), $10-17$.

Bailey, R., Armour, K., Kirk, D., Jess, M., Pickup, I., \& Sandford, R. (2009). The educational benefits claimed for physical education and school sport: An academic review. Research Papers in Education, 24(1), 1-27. https://doi.org/10.1080/02671520701809817

Brown, H. D. (2011). "Intrinsic Motivation in The Classroom”. Teaching By Principles, an integrative approach to language pedagogy, 2nd edition. San Fransisco: Perason Education.

Emda, A. (2018). Kedudukan Motivasi Belajar Siswa Dalam Pembelajaran. Lantanida Journal, 5(2), 172. https://doi.org/10.22373/lj.v5i2.2838 
Firmansyah, H. (2011). Hubungan Motivasi Berprestasi Siswa Dengan Hasil Belajar Pendidikan Jasmani. Jurnal Pendidikan Jasmani Indonesia, 6(1), 30-33.

Gunawan, I., \& Benty, D. D. N. (2007). Musyawarah Guru Mata Pelajaran dan Kemampuan Mengelola Kelas untuk Meningkatkan Motivasi Belajar Siswa. Manajemen Pendidikan, 20(1), 21-31.

Hamdu, G., \& Agustina, L. (2019). Pengaruh Motivasi Belajar Siswa Terhadap Hasil Belajar Ipa Di Sekolah Dasar. Edukatif : Jurnal Ilmu Pendidikan, 1(3), 280-286. https://doi.org/10.31004/edukatif.v1i3.63

Hidayatullah, F. (2017). Ketepatan Penggunaan Istilah Pada Pembelajaran Pendidikan Jasmani Materi Permainan Bola Besar Siswa Sekolah Menengah Pertama Negeri Kecamatan Bangkalan. Journal Proceeding, 1(1).

Indaryati, \& Jailani. (2015). Pengembangan Media Pembelajaran Matematka Dengan Flash. Jurnal Prima Edukasia, 3(1), 84-96. Retrieved from https://doi.org/10.24042/ajpm.v8i2.2014

Kusurkar, R. A., Ten Cate, T. J., Vos, C. M. P., Westers, P., \& Croiset, G. (2013). How motivation affects academic performance: A structural equation modelling analysis. Advances in Health Sciences Education, 18(1), 57-69. https://doi.org/10.1007/s 10459-012-9354-3

Moore, K. D. (2009). Effective instructional strategies from theory to practice 2nd edition. Los Angeles: SAGE Publications, Inc.

Muola, J. M. (2010). A study of the relationship between academic achievement motivation and home environment among standard eight pupils. Educational Research and Reviews, 5(5), 213-217. https://doi.org/10.5897/ERR09.039

Mustaqim, I. (2020). Pengaruh Kompetensi Dosen, Kurikulum Dan Motivasi Terhadap Prestasi Belajar Mahasiswa. Reslaj : Religion Education Social Laa Roiba Journal, 1(1), 63-75. https://doi.org/10.47467/reslaj.v1i1.67

Muta'al. (2019). Pengaruh Latihan Passing Dengan Variasi Target Terhadap Kemampuan Passing Pada Tim Sepakbola Sman 3 Bungo. Jurnal Stamina, 2(6), 12-20.

Naldi, I. Y., \& Irawan, R. (2020). Kontribusi Kemampuan Motorik Terhadap Kemampuan Teknik Dasar Pada Atlet Ssb (Sekolah Sepakbola) Balai Baru Kota Padang. Performa Olahraga, 5(1), 39-47.

Nashar. (2004). Peranan Motivasi dan Kemampuan Awal dalam Kegiatan Pembelajaran. Jakarta: Delia Press.

Nurhasan. (2013). Tes dan Pengukuran dalam Pendidikan Jasmani. Bandung: STKIP Pasundan.

Ormrod, J. E. (2003). Educational psychology developing learner. Upper Saddle River, NJ: Merrill Prentice Hall.

Sanjaya, W. (2010). Kurikulum dan pembelajaran, Teori dan praktek Pengembangan Kurikulum KTSP. Jakarta: Kencana.

Santrock, J. W. (2010). Psikologi pendidikan, edisi kedua. Diterjemahkan dari judul asli Educational psychologi, 2nd edition oleh Tri Wibowo B.S. Jakarta: Prenada Media Group.

Sardiman. (2018). Interaksi dan Motivasi Belajar Mengajar. Jakarta: Rajawali Pers.

Schunk, D. H. (2010). Motivation in education. Upper Saddle River: Pearson Education, Inc.

Suherman, A. (2009). Revitalisasi Pengajaran Dalam Pendidikan Jasmani. Bandung: 
Bintang Warli Artika.

Suminah, S., Gunawan, I., \& Murdiyah, S. (2019). Peningkatan Hasil Belajar dan Motivasi Belajar Siswa melalui Pendekatan Behavior Modification. Ilmu Pendidikan: Jurnal Kajian Teori Dan Praktik Kependidikan, 3(2), 221-230. https://doi.org/10.17977/um027v3i22018p221

Wijayanto, E. Z. (2012). Pengaruh Pembelajaran Permainan Bola Besar Terhadap Tingkat Kesegaran Jasmani. Active - Journal of Physical Education, Sport, Health and Recreation, 1(1). https://doi.org/10.15294/active.v1i1.264

Yudi, A. A. (2019). Pengaruh Latihan Small Sided Game Terhadap Keterampilan Passing Siswa SMAN 4 Sumbar. Jurnal Cerdas Sifa, (2), 1-8. 